\title{
Libero Gerosa*
}

\author{
INTERPRETACJA USTAW KANONICZNYCH \\ A NOWA EWANGELIZACJA: \\ innowacyjna lekcja świętego Jana Pawła II
}

W życiu osobistym i kościelnym nie ma zbiegów okoliczności, wydarzeń czysto przypadkowych, ponieważ wszystkie niosą ze sobą jakieś wezwanie, którego znaczenie rozjaśnia się wyłącznie, kiedy rozważane są jako element „obrazów Bożej Opatrzności”1. Dzisiaj możemy wyodrębnić trzy „okoliczności” naprawdę „tajemnicze”"2, a poprzez to bogate w głębokie znaczenie. Chodzi o 30. rocznicę wizyty Papieża Jana Pawła II na Katolickim Uniwersytecie Lubelskim, gdzie on sam był profesorem, która przypada w stulecie zarówno promulgacji pierwszego Kodeksu Prawa Kanonicznego Kościoła Katolickiego, jak i pierwszych objawień maryjnych w Fatimie. A wszystko to dzieje się dokładnie w dniu, w którym młoda karmelitanka św. Teresa z Lisieux, w odległym roku 1895, konsekrowała się Miłości Miłosiernej. Można się zdumieć! Przeanalizowanie najgłębszego znaczenia tych okoliczności w planach Bożej Opatrzności z pewnością wykracza poza zadanie niniejszego opracowania. Jest jednak możliwe, aby w każdej z nich rozeznać „pewną prawdę i wezwanie" ${ }^{3}$, które w pewien sposób wymagają komentarza dokonanego również przez kanonistę.

${ }^{*}$ Ks. prof. dr, Istituto Internazionale di Diritto Canonico e Diritto Comparato delle Religioni, Lugano.

${ }^{1}$ L. Zani, Era santo, era uomo. Il volto privato di Papa Wojtyla, Milano 2011, s. 153; tekst w j. polskim: L. Zani, Był człowiekiem, był świętym, Kraków 2014.

${ }^{2}$ Jest to określenie użyte przez Jana Pawła II w jego homilii z 13 maja 1982 r., wygłoszonej w Fatimie; zob. Giovanni Paolo II, L'omelia della Messa a Fatima. Il messaggio di Fatima si comprende alla luce dell'amore materno di Maria. 13.05.1982, [w:] Insegnamenti di Giovanni Paolo II, Città del Vaticano 1982, t. 5, cz. 2, s. 1579.

3 Tamże, s. 1580. 


\section{Wprowadzenie: potrójne ukierunkowanie teologiczne, podstawowe dla pracy hermeneutycznej współczesnego kanonisty}

Trzy wyżej wspomniane zbieżności „stanowią przestrzeń czasową" ${ }^{4}$ podążania ku poznaniu podstawowej prawdy i jako takie wpływają również na pracę hermeneutyczną kanonisty. Każda z nich czyni to na swój własny sposób.

\subsection{Ukierunkowanie na poznanie "wszystkiego"}

Pierwsza zbieżność, jak już zaznaczono, to fakt, iż 30. Rocznica wizyty Jana Pawła II przypada w stulecie promulgacji pierwszego Kodeksu Prawa Kanonicznego (1917 r.). W świetle jego przemówień wygłoszonych w Lublinie ${ }^{5}$, ta okoliczność podkreśla „prorocką moc” jego działalności również jako powszechnego prawodawcy Kościoła katolickiego.

Refleksje na temat roli uniwersytetu katolickiego, które dzisiaj już święty papież wówczas rozwinął, mogłyby zostać schematycznie streszczone w następującym stwierdzeniu: uniwersytet jest „miejscem nie tylko prawdy naukowej, ale i prawdy życia" ${ }^{\prime}$, ponieważ ze swej natury jest to „szczególne środowisko nastawione na poznanie wszystkiego"7. Jako, iż dla Jana Pawła II „wszystko” jest „zadane ludzkiemu poznaniu” jako takiemu, owo ukierunkowanie „ku wszystkiemu” dotyczy każdej dyscypliny naukowej nauczanej na uniwersytecie.

Dlatego też dziedziny naukowe, które na niego się składają podobnie jak kościoły, zwrócone ku wschodowi, są wszystkie ukierunkowane na Jezusa Chrystusa, Który jest „wszystkim” w rzeczywistości danej człowiekowi do poznania; więcej jeszcze. Jan Paweł II w jednym ze swoich przemówień

4 Tamże, s. 1585.

${ }^{5}$ Jest to podstawowa charakterystyka owych przemówień, zob. A. Vircondelet, Giovanni Paolo II. La biografia del Papa che ha cambiato la storia, Torino 2005, s. 323.

${ }^{6}$ Giovanni Paolo II, L'omelia durante Celebrazione della Parola nell'Università Cattolica di Lublino. Università! Alma mater! Se servi la verità, servi la libertà, la liberazione dell'uomo e della nazione. Servi la vita! 9.06.1987, 8, [w:] Insegnamenti di Giovanni Paolo II, Città del Vaticano 1987, t. 10, cz. 2, s. 2064-2072.

7 Tamże, 2. 
w Lublinie ${ }^{8}$, jako wytrawny fenomenolog precyzuje, że „cała rzeczywistość jest zadana człowiekowi pod kątem prawdy", dlatego też promowanie i umiłowanie prawdy jest "służbą człowiekowi”, a służba prawdzie jest służbą wolności człowieka9 i budowaniem wspólnoty ludzi wolnych. Jakże nie widzieć w tych stwierdzeniach pewnego źródła dla rozeznania z jasnością również ostatecznego celu prawa kanonicznego, którym jest budowanie communio Ecclesiae poprzez ochronę prawdy obiektywnej „wszystkiego”, zawartego w substantia verbi i substantia sacramenti, ochronę, ku której ze swej natury ukierunkowane są wszystkie struktury prawne Kościoła?

Innymi słowy, w świetle perspektywy nakreślonej przez Jana Pawła II w próbie zdefiniowania zadań każdego uniwersytetu katolickiego u progu III Tysiąclecia, tajemnicza dzisiejsza zbieżność ze stuleciem pierwszej kodyfikacji kanonicznej pozwala współczesnemu kanoniście na dojrzenie dokładnie wewnątrz tego intelektualnego „wszystkiego" zarówno wagi własnej pracy hermeneutycznej, jak też absolutnej nowości, jaką wycisnął na niej papież poprzez działalność legislacyjną. Aby pojąć tę nowość, wystarczy dokonać kilku porównań z dziełem kodyfikacyjnym zapoczątkowanym przez św. Piusa X. W rzeczywistości, choć może to wydawać się paradoksalne, jednoznacznie uznaje się, że „pontyfikat Piusa X, wyróżniający się poprzez szorstkość antymodernizmu, dał wsparcie i początek jednemu z typowych wytworów modernizmu i państwa modernistycznego w łonie Kościoła: kodyfikacji prawa"10. Jest również pewne, że ten pierw-

${ }^{8}$ Zob. tamże, 2 i 8, również komentarz do mądrościowego wersetu: „Mądrość wszystko zna i wszystko rozumie" (Mdr 9, 11) w encyklice Fides et ratio (14 września 1998 r.); zob. R. Fisichella (red.), Giovanni Paolo II. Tutte le encicliche, Città del Vaticano 2010, s. 2195-2203.

9 Zob. Giovanni Paolo II, Al mondo della cultura nell'Aula Magna dell'Università Cattolica di Lublino. La società attende dalle sue Università il consolidamento delle proprie soggettività. 9.06.1987, 2, [w]: Insegnamenti di Giovanni Paolo II, Città del Vaticano 1987, t. 10, cz. 2, s. 2054-2063: „Służąc prawdzie z miłości do prawdy i do tych, którym ją przekazujemy, budujemy wspólnotę ludzi wolnych w prawdzie, tworzymy wspólnotę ludzi zjednoczonych miłością do prawdy i miłością wzajemną w prawdzie, wspólnotę ludzi, dla których miłość prawdy stanowi zasadę jednoczącej ich więzi". Jest to rozwinięcie jakże aktualnych słów św. Pawła: „Aby Bóg był wszystkim we wszystkich” (1 Kor 15, 28).

${ }^{10}$ G. Romanato, Pio X. La vita di papa Sarto, Milano 1992, s. 315-316. Warto podkreślić, że spośród reform przeprowadzonych przez papieża Piusa X (liturgiczna i katechetyczna), „z całą pewnością to reforma prawa kanonicznego ukazuje jeden z największych sukcesów, nawet jeśli była później dopełniona przez jego następcę, Benedykta XV. Powody są natępujące: nowość kodyfikacji w Kościele, metoda i nakład pracy, waga i implikacje Codex Iuris Canonici z 1917 r.", C. Fantappiè, "Modernità" e "antimodernità" di Pio X, [w:] G. Brugnotto, G. Romanato (red.), Riforma del Cattolicesimo. Le attività e le scelte di Pio X, Città del Vaticano 2016, s. 30. 
szy Kodeks Prawa Kanonicznego, promulgowany w 1917 r., był „użytecznym narzędziem dla duszpasterstwa"11, przynajmniej $\mathrm{w}$ takim stopniu, w jakim był nim dla katechizacji niezwykle oryginalny Katechizm św. Piusa $X^{12}$. Jakkolwiek, jeśli te skonsolidowane pewniki w jakiś sposób moga pozwolić historykom na złagodzenie powszechnego wizerunku papieża jako „wrogo nastawionego do nowoczesności”"13, to pytają one również zarówno uważnego obserwatora, jak i prawodawcę kościelnego o sprawę fundamentalną dla całej współczesnej hermeneutyki kanonistycznej, to jest: czy na płaszczyźnie techniczno-prawnej narzędzie takie jak Codex jest naprawdę kompatybilne $\mathrm{z}$ samą istotą prawa kanonicznego ${ }^{14}$.

Na to pytanie Jan Paweł II odpowiedział poprzez działanie: już nie jeden tylko kodeks, ale dwa - jeden dla Kościoła Katolickiego obrządku łacińskiego (KPK) i jeden dla Kościołów Katolickich obrządków wschodnich (KKKW), które to Kodeksy, razem z Konstytucją Apostolską o Kurii Rzymskiej Pastor Bonus stanowią prawdziwy Corpus Iuris Canonici ${ }^{15}$, w służbie misji Kościoła w III Tysiącleciu. Ochrona jedności w różnorodności, czy też „wszystkiego" w "części” i na odwrót ${ }^{16}$, jest podstawowym

${ }_{11}$ G. Dalla Torre, Il codice di diritto canonico, [w:] G. La Bella (red.), Pio X e il suo tempo, Bologna 2003, s. 317; zob. C. Siccardi, San Pio X. Vita del Papa che ha ordinato e riformato la Chiesa, Cinisello Balsamo 2014, s. 269-276.

${ }^{12}$ W sprawie oceny oryginalności Katechizmu św. Piusa X, zob. C. Siccardi, San Pio X, s. 92-106, przede wszystkim s. 102.

${ }^{13}$ G. Dalla Torre, Il codice di diritto canonico, s. 330.

${ }^{14} \mathrm{Na}$ temat obiektywnych ograniczeń techniki kodyfikacji prawa kanonicznego zob. P. Grossi, Valore e limiti della codificazione del diritto (con qualche annotazione sulla scelta codicistica del legislatore canonico), [w:] A. Cattaneo (red.), L'eredità giuridica di San Pio X, Venezia 2006, s. 142; na temat potrzeby, aby pierwszy Kodeks Kościoła był, z woli papieża Piusa X, pomocny w pracy diecezji i proboszczów, w odpowiedzi na „,współczesne wymagania”, zob. C. Minelli, Pio X e la sistematica del Codex Iuris Canonici, [w:] Riforma del Cattolicesimo, s. 302-306. Debata na temat konieczności opowiedzenia się za prawdziwą kodyfikacją prawa kanonicznego, zainicjowana na początku XX w., wydaje się rozważać niektóre, ciągle aktualne, aspekty XIX-wiecznej polemiki dotyczącej kodyfikacji prawa cywilnego, zob. A.F.J. Thibaut, F.C. Savigny, La polemica sulla codificazione, G. Marini (red.), Napoli 1982.

${ }^{15} \mathrm{Na}$ temat wagi konstytucjonalnej i hermeneutycznej, jaką odznacza się ten Corpus podarowany przez Jana Pawła II Kościołowi III Tysiąclecia, zob. L. Gerosa, L'interpretazione della legge nella Chiesa. Principi, paradigmi, prospettive, Lugano 2001, s. 99-111.

${ }^{16}$ Jeśli nawet idea immanencji wszystkiego w części i części w całości jest u Jana Pawła II pod pewnym wpływem wielkiego teologa Hansa Ursa von Balthasara, jej aplikacja do prawa kanonicznego konstytucyjnego jest przynajmniej w jakiejś mierze zasługą szwajcarskiego kanonisty Eugenio Corecco, nawet, jeśli była obecna w zalążku w homilii wygłoszonej 12 czerwca 1984 r. w Lugano, zob. Giovanni Paolo II, Omelia alla messa celebrata a Lugano. La Chiesa nella dimensione universale e locale è l'ambiente della nuova esistenza 
zadaniem współczesnej hermeneutyki kanonistycznej. Jako takie zadanie to jest życiowym ukierunkowaniem dla pracy każdego kanonisty.

\subsection{Ukierunkowanie na uświęcenie jako „udoskonalanie miłości"}

Druga zbieżność, mówiąca o tym, że 30. rocznica wizyty Jana Pawła II przypada w stulecie pierwszych objawień w Fatimie, jest dla każdego teologa, a zatem również kanonisty, jasnym zaproszeniem do zdania sobie sprawy we własnej pracy hermeneutycznej z faktu, że dla Magisterium i aktywności duszpastersko-prawodawczej Jana Pawła II decydującą rolę z pewnością odgrywała pobożność maryjna. Decydującą nie tylko dla jego osobistego doświadczenia wiary ${ }^{17}$, ale również i przede wszystkim dla jego głęboko soborowej wizji Kościoła jako komunii: „Prawdziwa pobożność maryjna jest chrystocentryczna [...i jako taka jest uprzywilejowanym narzędziem...] do pełnego odnalezienia Jezusa Chrystusa, aby szczerze Go umiłować i wiernie Mu służyć" $(V D, 62)$. Dzieje się tak, ponieważ analogicznie do prorockiej mocy ukierunkowanej na „wszystko” ukazane w pierwszej zbieżności, prawdziwa pobożność maryjna pomaga wiernemu w odczytywaniu „,znaków czasu”"18, jak to szeroko ukazuje Jan Paweł II w Encyklice Redemptoris Mater ${ }^{19}$.

dell'uomo. 12.06.1984, [w:] Insegnamenti di Giovanni Paolo II, Città del Vaticano 1984, t. 7, cz. 1, s. 1676-1683; szczegółowy komentarz: L. Gerosa, L'interpretazione della legge nella Chiesa, s. 47-61.

17 Szerzej zob. F.M. Lethel, La luce di Cristo nel cuore della Chiesa. Giovanni Paolo II e la teologia dei santi. Esercizi spirituali con Benedetto XVI, Città del Vaticano 2011, s. 40-42. Na temat tego, jak mocnym doświadczeniem, charakteryzujacym całą istotę i działanie Jana Pawła II, stała się Fatima, zob. J. Meisner, Als Maria das Heft in die Hand nahm, Gespräch mit R. Einig u. O. Maksan, „Die Tagespost” 13.09.16, s. 7. O wadze Fatimy dla historii i teologii Kościoła katolickiego, zob. M. Hauke (red.), Die Marienerscheinungen - 100 Jahre danach: Geschichte, Rezeption und Bedentung, Regensburg 2017. Wymowne jest wyznanie samego Jana Pawła II: „Nie byłoby na Stolicy Piotrowej tego papieża Polaka [...] gdyby nie było Jasnej Góry", zob. A. Riccardi, Giovanni Paolo II. La biografia, Cinisello Balsamo 2011, s. 31.

${ }_{18}$ Zgadzają się z tą opinią: J. Ratzinger, Un'interpretazione dei segni dei tempi per il cammino della Chiesa e dell'umanità. Conferenza di presentazione dell'enciclica "Redemptoris Mater", „L'Osservatore Romano” 26.03.1987, s. 1; R. Fisichella, Prefazione, [w:] R. Fisichella (red.), Giovanni Paolo II. Tutte le encicliche, Città del Vaticano 2010, s. 759-769.

19 Zob. Jan Paweł II, Encyklika "Redemptoris Mater". 25.03.1987, AAS 79(1987) 361-433. Na temat znaczenia prorockiego, zob. A. Cazzago, Cristianesimo d'Oriente e d'Occidente in Giovanni Paolo II, Milano 1996, s. 93-100. 
Poza tym omawiane doświadczenie charakteryzuje się nie tylko silną świadomością odnoszącą się do łącznika pomiędzy tym, co wydarzyło się w odległym 1917 r., a dramatycznym zamachem na Placu św. Piotra $^{20}$, ale również - i przede wszystkim - świadomościa że „doskonalenie miłości" ${ }^{21}$ jest świętością Kościoła, a poprzez to komunią z Bogiem i bliźnimi. Communio Ecclesiae nie jest tylko jakimś bliżej nieokreślonym uczuciem, ale, jak naucza Sobór Watykański II w Nota praevia do Konstytucji Lumen Gentium, strukturalną rzeczywistościa, zasadą która przewodzi $\mathrm{w}$ całym kanonicznym porządku, w prawie kanonicznym, jego aplikacji i interpretacji ${ }^{22}$. Oczywiście nie oznacza to, że wszystko to, co kryje się pod nowotestamentalnym terminem communio musi być koniecznie sformalizowane i ukazane również na płaszczyźnie prawnej. Nie oznacza to również, że musi być pełna zgodność pomiędzy communio eucharistica ${ }^{23}$ i komunią kościelną, albo, że obowiązki wskazane w kan. 210, mówiącym o tym, iż wszyscy wierni winni starać się prowadzić życie święte i przyczyniać się do wzrostu Kościoła, mają naturę prawną ${ }^{24}$. Oznacza to tylko, że zgodnie z mens legislatoris nie można zanegować ani faktu, że przytoczona norma kodeksowa wiernie odzwierciedla nauczanie Soboru Watykańskiego II, który naucza, że „wszyscy w Kościele [...] powołani są do świętości" (KK 39), ani tego, że jej kolokacja systematyczna na początku katalogu praw i obowiązków wszystkich wiernych jest bezwzględnie koniecznym rozjaśnieniem tego, o czym mówił kan. 593 Kodeksu z 1917 r., gdzie podobny obowiązek był ustanowiony tylko dla zakonników. Jeśli zatem kan. 211 (o wydźwięku jeszcze bardziej ogólnym) ustanawia

${ }^{20}$ Szerzej zob. L. Zani, Era santo, era uomo, s. 117.

21 Zob. F.M. Lethel, La luce di Cristo nel cuore della Chiesa, s. 52-58.

${ }^{22}$ Szerzej zob. H. Müller, Utrum „communio" sit principium formale-canonicum novae codificationis Iuris Canonici Ecclesiae Latinae?, „Periodica” 1985, t. 74, s. 107; R. Sobański, La Chiesa e il suo diritto. Realtà teologica e giuridica del diritto ecclesiale, Torino 1993 (rozdział: Communio: principio di dinamicità del diritto ecclesiale); ale również obszerne dzieło historyczno-krytyczne C. Fantappiè, gdzie w podsumowaniu autor stwierdza: „odnowa, jaką przyniósł Sobór Watykański II, domaga się istotnego wkładu nauki kanonistycznej: musi ona nie tylko uzupełnić własne podejście do nowej eklezjologii, ale również wnieść swój specyficzny wkład do jej spójnej aplikacji. Nauczanie communio będzie w Kościele mało znaczącym ideałem, jeśli nie będzie się przekładało na «konkretne i zasadnicze struktury», które będą wcielały w życie i porządkowały zasady współodpowiedzialności, synodalności i kolegialności", zob. tenże, Ecclesiologia e canonistica, Venezia 2015, s. 356.

${ }_{23}$ Zob. R. Ahlers, Communio Eucharistica. Eine kirchenrechtliche Untersuchung zur Eucharistielehre in Codex Iuris Canonici, Regensburg 1990, s. 81-85.

${ }^{24}$ Szerzej zob. L. Müller, Fede e diritto. Questioni fondamentali del diritto canonico, Lugano 2006, s. 211-222. 
$\mathrm{w}$ odniesieniu do wszystkich wiernych obowiazek $i$ prawo ewangelizacji, które zostaną później skonkretyzowane w kann. 756-759, to jest to tylko prostą konsekwencją obowiązku przyczyniania się do świętości i wzrostu Kościoła, ustanowionego w kan. 210. „Prawo do otrzymywania dóbr duchowych, w rozumieniu kan. 213, odpowiada obowiązkowi uświęcania siebie i Kościoła. To samo można powiedzieć odnośnie do prawa do sprawowania kultu Bożego, zgodnie z kan. 214, czy też na temat prawa do dopuszczenia do sakramentów, które stoi u podstaw regulacji zawartej w kan. $843 \S 1$. W ten sam sposób również norma wyrażona w kan. 1364, mówiąca o przestępstwach przeciwko religii, tj. apostazji, herezji i schizmie, może być interpretowana jako konsekwencja obowiązków ustanowionych w kan. 210"25.

Jednym słowem, w świetle doświadczenia maryjnego i heroicznego zaangażowania Jana Pawła II w uświęcenie siebie samego i całego Kościoła, można by podsumować mówiąc, że kan. 210 KPK ma podwójna, konkretną funkcję: wskazywać na ostateczna, teologiczną podstawę wielu innych norm kodeksowych, zatem funkcję bycia równocześnie „kanonem hermeneutycznym całego prawa kanonicznego" ${ }^{26}$. Oznacza to, że promowanie wzrostu i uświęcenia Kościoła jest podstawowym elementem thelosu charakteryzującego jego wszystkie struktury prawne. Innymi słowy, konkretna realizacja ostatecznego celu prawa kanonicznego, to jest communio, wymaga szczególnej i ciągłej uwagi ukierunkowanej na salus animarum, wskazanej przez kan. 1752, ostatni w KPK, jako suprema lex w Kościele ${ }^{27}$. Wymaga się tego przede wszystkim, kiedy trzeba uchwycić rzeczywistą treść normatywną ustawy kościelnej, poczynając od jej "tekstu” i „kontekstu”, jak również jej „miejsc paralelnych” i „okoliczności” (kan. 17), a w dalszej kolejności, kiedy mówi się o rozeznaniu rzeczywistej „myśli prawodawcy” (kan. 17). Ostatecznie dwojaki obowiązek "prowadzenia życia świętego" i „przyczyniania się do wzrostu Kościoła i ustawicznego wspierania rozwoju jego świętości" (kan. 210) jest jednym z podsta-

25 Tamże, s. 221.

${ }^{26}$ Jest to stwierdzenie G. Dalla Torre (zob. tenże, Santità e diritto. Sondaggi nella storia del diritto canonico, Torino 1999, s. 2), który ośmiela się zaaplikować je do numeru 8 KK, w którym Sobór Watykański II stwierdza, że „Kościół ziemski i Kościół - bogaty w dary niebiańskie - nie mogą być pojmowane jako dwie rzeczy odrębne, przeciwnie, tworzą one jedną rzeczywistość złożoną".

${ }^{27} \mathrm{Na}$ temat wagi hermeneutycznej tego kanonu zob. przede wszystkim J. Herranz, F.J. Errázuriz, J.I. Arrieta w monografii zatytułowanej La salus animarum nell'esperienza giuridica della Chiesa, „Ius Ecclesiae” 12(2000), s. 291-529. 
wowych założeń poprawnej hermeneutyki kanonistycznej, odnowionej w jakże znaczący sposób przez papieża Jana Pawła II. Na Katolickim Uniwersytecie Lubelskim przypominał o tym również bp Eugenio Corecco, w czasie wręczania mu doktoratu honoris causa, kiedy to dla wyjaśnienia wagi hermeneutycznej pryncypium salus animarum stwierdził: „Prawo kanoniczne nie jest nadbudową socjologiczną Kościoła. Nie jest czystym dodatkiem, bez żadnej własnej treści soteriologicznej, lecz jest fenomenem społecznym, posiadającym własną autonomię epistemologiczną i logiczną. W mocy wiążącej jego całościowej rzeczywistości, ukazuje się i przez nie może być poznany Kościół. Stąd też dążenie Kościoła łacińskiego do całkowicie precyzyjnego ustanowienia zgodności w relacjach pomiędzy własną świadomością dogmatyczną a porządkiem prawnym, pochodzi ze specyficznego sposobu rozumienia samego dogmatu. Jest to tradycja inna zarówno od tradycji prawosławnej, jak też tej protestanckiej”"28.

\subsection{Ukierunkowanie na ochronę "communio", połączone z promocją konkretnego doświadczenia miłosierdzia}

Trzecia i ostatnia zbieżność, to dzień 9 czerwca, to jest dokładnie dzień, w którym św. Teresa z Lisieux konsekrowała się Miłości Miłosiernej. Ta święta karmelitanka pozwoliła Janowi Pawłowi II na jasne ukazanie, zwłaszcza w nr 42 Novo millennio ineunte ${ }^{29}$, komplementarności i nierozdzielności dochodzenia teologicznego, scientia fidei, i teologii wcielonej $\mathrm{w}$ życie u świętych, scientia amoris ${ }^{30}$. Zbieżność ta niesie za sobą mocne wezwanie skierowane do wszystkich wiernych, włącznie z teologami i kanonistami: jeśli Boże Miłosierdzie jest granicą postawioną złu w człowieku przez Pana Boga (Fatima), zawierzenie Bożemu Miłosierdziu będzie autentyczne tylko wtedy, gdy osobisty dar będzie współgrał z odpowiedzialną pracą przeciwko degradacji człowieka i jego synowskiej godności31.

${ }^{28}$ E. Corecco, Il valore della norma canonica in rapporto alla salvezza, [w:] G. Borgonovo, A. Cattaneo (red.), Eugenio Corecco. Ius et communio. Scritti di Diritto Canonico, t. 1, LuganoCasale Monferrato 1997, s. 57-64.

29 Tekst oryginalny: AAS 93 (2001) 266-309.

${ }^{30}$ Komentarz: F.M. Lethel, La luce di Cristo nel cuore della Chiesa, s. 29-32.

31 Jest to zasadnicza treść przemówienia Jana Pawła II po Apelu Jasnogórskim z 12 czerwca 1987 r., zob. Giovanni Paolo II, Il discorso a Częstochowa dopo "l'appello di Jasna Góra". Non è lecito permettere la degradazione degli uomini mentre ci si è assunti per essi la responsabilità davanti alla storia. 12.06.1987, [w:] Insegnamenti di Giovanni Paolo II, Città del Vaticano 
Dlatego też w całym swoim papieskim nauczaniu Jan Paweł II nie przestaje podkreślać centralnej roli sakramentu pokuty na każdej płaszczyźnie, zarówno duszpasterskiej, jak i prawnej ${ }^{32}$, a przede wszystkim w stawianiu czoła głównemu wyzwaniu III Tysiąclecia, o czym przypomina Jan Paweł II na zakończenie Wielkiego Jubileuszu Roku 2000: „Czynić Kościót domem i szkoła komunii: oto wielkie wyzwanie, jakie czeka nas w rozpoczynającym się tysiącleciu, jeśli chcemy pozostać wierni Bożemu zamystowi, a jednocześnie odpowiedzieć na najgłębsze oczekiwania świata. Co to oznacza w praktyce? Także tutaj można by bezpośrednio przejść na płaszczyznę działania, ale błędem byłoby ulec tej pokusie. Zanim przystąpimy do programowania konkretnych przedsięwzięć, należy krzewić duchowość komunii, podkreślając jej znaczenie jako zasady wychowawczej wszędzie tam, gdzie kształtuje się człowiek i chrześcijanin"33. Pośród różnych miejsc, nadrzędnym jest konfesjonał, ponieważ, jeśli Kościół jest urzeczywistnieniem komunii, zanurzonej na sposób ciągły w wychodzeniu naprzeciw sercu każdego człowieka, nie ma niczego, co mogłoby „przeniknąć do serc i sumien'" dogłębnie je formując, jak tylko duszpasterstwo zakorzenione w konkretnym doświadczeniu Bożego Miłosierdzia ${ }^{34}$. Oznacza to uczynienie z osobistego towarzyszenia (lub cura spiritualis) centralnej osi, wokół której należy rozwinąć organiczną i wspólnotową cura animarum. Jest to jakże wymowne i aktualne nauczanie o wzruszeniu Serca Jezusowego: „A widząc tłumy ludzi, litował się nad nimi, bo byli znękani i porzuceni, jak owce nie mające pasterza" (Mt 9, 36), które papież Franciszek zdaje się przywoływać, ilekroć podkreśla wagę osobistego towarzyszenia w procesie wzrostu świadomości misyjnej Kościoła, ponieważ tzw. sztuka towarzyszenia lub towarzyszenie duchowe każdej osobie powinno coraz bardziej prowadzić do Boga, w którym możemy zdobyć prawdziwa wolność35. Dokładnie na poziomie tego „pielgrzymowania z Chrystusem do Ojca”, pielgrzymki, któ-

1987, t. 10, cz. 2, s. 2180-2185; na temat ofiary z siebie Miłości Miłosiernej, dokonanej przez św. Teresę z Lisieux, zob. C. De Meester, L'offerta all'amore misericordioso, [w:] Teresa di Lisieux. Vita, dottrina, ambiente, Cinisello Balsamo 1996, tutaj s. 159.

${ }^{32}$ Zob. L. Gerosa, Dove nasce l'uomo vero? Per un esercizio autentico della Misericordia, Lugano-Siena 2016, s. 58-92, również w j. polskim: L. Gerosa, Gdzie rodzi sie prawdziwy człowiek? Doświadczenie autentycznego Miłosierdzia, Białystok 2016, s. 69-105.

33 Jan Paweł II, Novo millenio ineunte, 43.

${ }^{34}$ Przepowiada to prorocko największa filozof XX w., dzisiaj święta: „Nigdy nie podobało mi się myśleć, że Boże Miłosierdzie zatrzymuje się na granicy Kościoła widzialnego. Bóg jest prawdą! Kto szuka prawdy, szuka Boga, nawet jeśli nie jest tego świadom", E. Stein, La scelta di Dio. Lettere, Roma 1974², s. 124.

${ }_{35}$ Franciszek, Evangelii gaudium, 170. 
re będą miały za cel Ojca Miłosiernego, Jan Paweł II potrafił wprowadzić do normatywy kanonistycznej Kościoła łacińskiego prawdziwe novum, to jest cały rozdział (kann. 1230-1234) zadedykowany sanktuariom, znajdujący się w Księdze IV: Uświęcające zadanie Kościoła; rozdziału tego o dziwo nie było w starym kodeksie z $1917 \mathrm{r}^{36}$

Ta normatywna nowość, wespół z wieloma innymi, wprowadzonymi do prawa kanonicznego Kościoła III Tysiąclecia przez papieża Jana Pawła II, nie może pozostać niezauważona dla tego, kto na poziomie naukowym i duszpasterskim widzi konieczność stawienia czoła interpretacji i aplikacji ustawy kanonicznej. Jest to istotne zwłaszcza wówczas, gdy chce to robić $\mathrm{w}$ zgodzie $\mathrm{z}$ tradycyjnym pryncypium aequitas canonica, jedynym będącym w stanie ukazać wewnętrzny i głęboki związek z miłosierdziem ${ }^{37}$.

Obecnie, zwłaszcza po publikacji listu papieża Franciszka do Wielkiego Kanclerza Papieskiego Uniwersytetu Katolickiego Argentyny ${ }^{38}$, w którym stwierdza on, że bez miłosierdzia zarówno teologia, jak i prawo kanoniczne ryzykuja że zostaną zredukowane do biurokracji (a nawet ideologii), ukazało się wiele publikacji naukowych na ten temat ${ }^{39}$. W tym miejscu pragnie się tylko przypomnieć, że zasługa tej odnowy metodologicznej i epistemologicznej ma swoje głębokie korzenie (pośród których wyróżniają się z uwagi na swoją wagę fundamenty filozoficzne aktywności legislacyjnej Jana Pawła II) w silnym czynniku twórczym wartości moralnej, etycznej i artystycznej godności każdej osoby ludzkiej. To ukierunkowanie na całkowity szacunek wobec ludzkiego sumienia, zostało zdefiniowane

${ }^{36}$ Dla dokładniejszej analizy tej nowej normatywy kodeksowej, zob. M. Calvi, I santuari nel nuovo Codice di diritto canonico, "Quaderni di Diritto Ecclesiale" 1989, nr 2, s. 181187; V. Fagiolo, Problemi giuridici riguardanti i santuari, „La Madonna” 35(1987), s. 58-75; G. Feliciani, La disciplina canonica dei santuari, [w:] G. Dammacco, G. Otranto (red.), Profili giuridici e storia dei santuari cristiani in Italia, Bari 2004, s. 31-44; jak również praca licencjacka z prawa kanonicznego ks. Krystiana Nowickiego, napisana pod kierunkiem autora tego artykułu.

${ }^{37}$ Ustawa kościelna została zdefiniowana przez kanonistykę średniowieczną jako iustitia dulcore misericordia temperata, zob. H. Müller, Aequitas canonica, [w:] W. Kasper (red.), Lexikon für Theologie und Kirche, t. 1, Friburg-Basel-Rom-Wien 1993, kol. 185.

38 Zob. Lettera del Santo Padre Francesco al Gran Cancelliere della Pontificia Universidad Católica Argentina, http://w2.vatican.va/content/francesco/it/letters/2015/documents/papa-francesco_20150303_lettera-universita-cattolica-argentina.html [dostęp: 08.08.2018 r.].

39 Szerzej na ten temat zob. J. Arrieta, Barmherzigkeit und kanonisches Recht. Die Erfahrung des lateinischen Kirchenrechts und die hermeneutische Aufgabe der Mediation , "Archiv für Katholisches Kirchenrecht" 2015, t. 184, s. 16-33; G. Dalla Torre, Giustizia e misericordia, „Ephemerides Iuris Canonici” 2016, t. 56, z. 1, s. 175-194. 
przez młodego biskupa Wojtyłę na długo przed wyniesieniem go na papieski tron ${ }^{40}$. To właśnie owa godność osoby ludzkiej jest punktem stycznym pomiędzy prawem kanonicznym i miłosierdziem, ponieważ - jak naucza św. Jan Paweł II we wspaniałej encyklice Dives in Misericordia ${ }^{41}$, komentując przypowieść o synu marnotrawnym (Łk 15, 11-32) - „relacja miłosierdzia opiera się na wspólnym przeżyciu tego dobra, jakim jest człowiek, na wspólnym doświadczeniu tej godności, jaka jest jemu właściwa" (nr 6).

Podsumowując: potrójne ukierunkowanie hermeneutyczne, zasugerowane przez trzy okoliczności, to jest konieczność interpretacji konkretnej normy kanonicznej zawsze w świetle jej funkcji globalnej w porządku prawnym Kościoła, funkcji, której nie można oddzielić od powszechnego powołania do świętości, możliwego do realizacji tylko na mocy konkretnego doświadczenia Bożego Miłosierdzia, może być w pełni dostrzeżone ze wszystkimi konsekwencjami duszpasterskimi wewnątrz technicznych współrzędnych ustalonych przez papieża Jana Pawła II dla współczesnej kanonistyki. Warto zatem przyglądać się im ciągle na nowo i zgłębiać je, a przez to jasno odkrywać ich innowacyjną siłę, która jest w stanie efektywnie wzmacniać misyjny charakter wszystkich struktur prawnych Kościoła.

\section{Podstawowe współrzędne techniczne współczesnej hermeneutyki kanonistycznej}

W pełnej zgodności z centralnym stwierdzeniem Dokumentu z Aparecidy, zgodnie z którym „misyjna działalność jest paradygmatem każde-

${ }^{40}$ Warto zapoznać się $\mathrm{z}$ treścią medytacji wygłoszonych w Krakowie, w odległym roku 1962, opublikowanych w: K. Wojtyla, Il Vangelo e l'arte. Esercizi spirituali per gli artisti, Città del Vaticano 2013, s. 23-25, tekst w j. polskim: K. Wojtyła - Jan Paweł II, Ewangelia a sztuka. Rekolekcje dla artystów, Kraków 2016.

${ }^{41}$ Poza tym w wersecie 31. ewangelista Łukasz, mówiąc o odnalezionej godności, używa dokładnie słowa klucza przemówień Jana Pawła II w Lublinie, to jest „wszystko”! Jedność pomiędzy jego doświadczeniem mistycznym, a trudem jaki zadał sobie broniąc godności osoby ludzkiej ukazuje również jego krótki komentarz do słów „przyjaciółka”, „siostra” i „oblubienica” w księdze Pieśni nad Pieśniami, zob. Giovanni Paolo II, Catechesi sul segno sacramentale del matrimonio. 30.05.1984, [w:] Insegnamenti di Giovanni Paolo II, t. 7, cz. 1, Città del Vaticano 1984, s. 1561. O wadze tej wypowiedzi, zob. G. Ravasi, Cantico dei Cantici.... Come sigillo sul cuore, Cinisello Balsamo 2011, s. 35. 
go dzieła w Kościele" ${ }^{42}$, w paragrafach wstępnych adhortacji apostolskiej Evangelii gaudium papież Franciszek zachęca do przejścia „od duszpasterstwa zwykłego zachowywania stanu rzeczy do duszpasterstwa zdecydowanie misyjnego" ${ }^{\prime 43}$. Jest to przejście absolutnie konieczne, które zakłada: na poziomie legislacyjnym kanonicznym „reformę struktur” prawnych, aby ",stały się one wszystkie bardziej misyjne" ${ }^{44}$, na poziomie zaś ich konkretnej aplikacji, oznacza to, że każdy „biskup powinien ukazać znak nawrócenia struktur kościelnych" ${ }^{45}$.

Wszystko to nie będzie możliwe, jeśli papież i biskupi nie będą wsparci pracą hermeneutyczną kanonistów, która to praca, jak stwierdził papież Benedykt XVI, „nie jest już zwykłym stosowaniem logiki. Chodzi o zadanie ożywiane autentycznym kontaktem z całościowa rzeczywistościa Kościoła, pozwalającym wniknąć w prawdziwwy sens litery prawa"46; zaś ten prawdziwy sens ustaw kościelnych wskazuje zawsze - jak stwierdził św. Jan Paweł II - na „centralną wartość osoby ludzkiej”, wartość „rozszerzoną przez jej ciągłe interreakcje z rzeczywistością komunii kościelnej" ${ }^{\prime 4}$.

Centralne miejsce osoby ludzkiej w każdym liczącym się porządku prawnym, jak również jej ontologiczne rozszerzenie dokonujące się w komunii kościelnej, jako przedmiocie formalnym prawa kościelnego, charakteryzują wielki wkład Jana Pawła II w rozwój prawa kanonicznego, $\mathrm{w}$ jego interpretację misyjną i jego aplikację w "czasie miłosierdzia”48. To właśnie do nich należy się odwoływać, jako fundamentów i pryncypiów

${ }^{42}$ V Conferenza Generale dell'Episcopato Latino-Americano e dei Caraibi, Documento di Aparecida. 31.05. 2007 r., s. 548, tutaj cytowany za: Francesco, Esortazione apostolica "Evangelii gaudium", Città del Vaticano 2013, s. 45.

${ }_{43}$ Francesco, Evangelii gaudium, 15.

${ }_{44}$ Tamże, 27.

${ }^{45}$ Jest to trzecie podstawowe kryterium, ukazane przez papieża Franciszka we wprowadzeniu do listu apostolskiego Mitis Iudex Dominus Iesus (8 września 2015 r.), Franciszek, List apostolski motu proprio "Mitis Iudex Dominus Iesus" reformujacy kanony Kodeksu Prawa Kanonicznego dotyczace spraw o orzeczenie nieważności małżeństwa, http://w2.vatican.va/content/ francesco/pl/motu_proprio/documents/papa-francesco-motu-proprio_20150815_mitis-iudex-dominus-iesus.html [dostęp: 9.08.2018 r.].

${ }^{46}$ Benedetto XVI, Discorso in occasione dell'inaugurazione dell'anno giudiziario del Tribunale della Rota Romana. 21.01.2012, AAS 104(2012) 103-107.

${ }^{47}$ Jan Paweł II, List Apostolski "Novo millennio ineunte". 6.01.2001, AAS 93(2001) 266309.

${ }^{48}$ Fakt, że początek III Tysiąclecia jest „konkretnie czasem miłosierdzia”, to - według papieża Franciszka - zasługa intuicji św. Jana Pawła II: „On przewidział, że to był czas miłosierdzia...", Francesco, Camminare con Gesù. Il cuore della vita cristiana, G. Vigini (red.), Cinisello Balsamo 2014, s. 138. 
założycielskich całej odnowy metodologicznej i epistemologicznej prawa kanonicznego na początku III Tysiąclecia, a zatem hermeneutyki kanonistycznej ze wszystkim, co jej dotyczy.

Są zatem dwa poziomy, na których należy przeprowadzić ocenę wkładu Jana Pawła II do odnowy prawa kanonicznego: poziom jego aktywności legislacyjnej oraz poziom jego wkładu w rozwój metodologiczny i epistemologiczny nauki kanonistycznej.

\subsection{Ważniejsze nowości w aktywności legislacyjnej Jana Pawła II}

Nowości tych jest przynajmniej sześć. Oto i one.

Przede wszystkim należy ukazać fakt, że Jan Paweł II jest pierwszym papieżem $\mathrm{w}$ historii, który promulgował dwa kodeksy prawa kanonicznego, jeden dla Kościoła katolickiego łacińskiego (KPK) oraz jeden dla 21 Kościołów wschodnich (KKKW), będąc przekonanym, że Kościół, aby być w pełni katolicki, powszechny, „musi mieć dwa płuca, wschodnie i zachodnie" 49 .

Na drugim miejscu papież Jan Paweł II nie wykluczył teoretycznie możliwości dojścia do promulgacji wewnątrz tzw. communio Ecclesiarum wielu zbiorów praw, ustaw kanonicznych partykularnych, po jednym dla każdego kontynentu; potwierdza to jego prorocka intuicja, która ukazała się, gdy zwołał synody biskupie dla konkretnych kontynentów, nie tylko dla Europy, ale również pozostałych czterech, w czasie których wzywał do refleksji nad ewangelizacją ${ }^{50}$.

Na trzecim miejscu należy podkreślić fakt, że pierwszy kodeks promulgowany w 1983 r. przez Jana Pawła II jest jednogłośnie uznany prawdziwym kamieniem milowym na otwartej przez niego drodze do całkowitej odnowy całego prawa Kościoła katolickiego. Dlatego też Kodeks uznaje się nie za „punkt dojścia”, ale za „punkt wyjścia” ${ }^{51}$. Rzeczywiście, lista do-

${ }^{49}$ W czasie swoich podróży apostolskich i w swoich pismach, papież Jan Paweł II wielokrotnie mówił o Europie, która oddycha "dwoma płucami”, zob. A. Riccardi, Giovanni Paolo II. La biografia, San Paolo-Cinisello Balsamo 2011, s. 160.

50 Szerzej na ten temat zob. E. Corecco, Prospettive per la "Lex Ecclesiae fundamentalis" e la revisione del diritto canonico nel documento di Puebla, „Il Diritto Ecclesiastico” 1980, t. 91, z. 1, s. 3-23; L. Gerosa, L'interpretazione della legge nella Chiesa, s. 47-61, tekst w j. polskim: L. Gerosa, Interpretacja prawa w Kościele. Zasady, wzorce, perspektywy, Kraków 2003.

${ }^{51}$ J. Herranz, Il Codice di Diritto canonico e il successivo sviluppo normativo, [w:] La legge canonica nella vita della Chiesa. Indagine e prospettive nel segno del recente magistero pontificio. 
kumentów prawnych, które odtąd podążały tą drogą jest długa, a pośród nich wyróżnia się Konstytucja Apostolska o Kurii Rzymskiej, opublikowana w 1988 r. ${ }^{52} \mathrm{~W}$ całości te teksty legislacyjne stanowią prawdziwy nowy Corpus Iuris Canonici, który, jak powiedział sam papież Jan Paweł II ${ }^{53}$, należy rozumieć jako narzędzie "odpowiadające w pełni naturze Kościoła”, a więc jako „narzędzie komunii” w „służbie głębokiej tajemnicy łaski”.

Jakby tego było mało, na czwartym miejscu, choć innowacyjna płodność prawodawcy nie ma nic, albo niewiele wspólnego, z małą lub wielką ilością ustaw przez niego promulgowanych, papież Jan Paweł II bez wątpliwości chciał prawnie potwierdzić wewnętrzna żywotność $i$ dynamizm tego ciała [narzędzia] normatywnego ${ }^{54}$, przez niego samego ciągle aktualizowanego, integrowanego i udoskonalanego; mówił, precyzując expressis verbis, że „w rzeczywistości autentyczna interpretacja słowa Bożego, jakiej dokonuje Magisterium Kościoła, ma wartość prawna, w takiej mierze, w jakiej dotyczy dziedziny prawa, i nie potrzebuje żadnej dodatkowej formalizacji, aby stać się prawnie i moralnie wiążącą"55. Innymi słowy, nie tylko ustawy kanoniczne, formalnie promulgowane jako takie, ale również inne elementy Magisterium papieskiego o naturze przeważająco duszpasterskiej lub nauczanie, mogą mieć wagę prawną której nie należy pomijać, a wypadałoby umieścić razem z ustawami kanonicznymi, dekretami generalnymi i instrukcjami w kompozycji tej całości, która tworzy Corpus Iuris Canonici, będący w stanie przetrzeć ",szlak Piotrowej łodzi”"56.

Po piąte należy przypomnieć, że niezaprzeczalnie wielka działalność prawodawcza Jana Pawła II koresponduje z równie wielkim i innowacyjnym trudem uaktualniania i kompletowania kodyfikowanych ustaw ka-

Atti del Convegno di studio tenutosi nel XXV anniversario della promulgazione del Codice di Diritto Canonico, Città del Vaticano 2008, s. 48 i 50.

52 Oficjalny tekst Konstytucji Apostolskiej "Pastor bonus”, AAS 80(1988) 841-934.

53 Zob. Jan Paweł II, Konstytucja Apostolska "Sacrae disciplinae leges", 11, AAS 75(1983), pars II; Tenże, Pastor bonus, 2; Tenże, Przemówienie do "Common Law Society of Great Britain and Ireland". 22.05.1992, "Communicationes" 24 (1992), s. 10; jednoznaczne stanowisko prezentuje: J. Herranz, Il Codice di Diritto canonico e il successivo sviluppo normativo, s. 53-55; P. Erdö, Rigidità ed elasticità delle strutture normative nel dialogo ecumenico, [w:] La legge canonica nella vita della Chiesa, s. 167.

${ }^{54}$ Zob. J. Herranz, Il Codice di Diritto canonico e il successivo sviluppo normativo, s. 56.

55 Giovanni Paolo II, Discorso di Giovanni Paolo II al Tribunale della Rota Romana in occasione dell'inaugurazione dell'Anno Giudiziario. 29.01.2005, 6, http://w2.vatican.va/content/ john-paul-ii/it/speeches/2005/january/documents/hf_jp-ii_spe_20050129_roman-rota.html [dostęp: 9.08.2018 r.]; tekst także w: AAS 97(2005) 166.

56 J. Herranz, Il Codice di Diritto canonico e il successivo sviluppo normativo, s. 53. 
nonicznych. Przejawia się to przede wszystkim w recepcji ważnych kategorii teologicznych Soboru Watykańskiego II, to jest: pojęcia Ludu Bożego, dla zdefiniowania struktury organizacyjnej Kościoła; pojęcia służby, dla uchwycenia zadania hierarchii; komunii, dla ustanowienia udziału wszystkich wiernych w misji Kościoła, czy też ogólne umiejscowienie prawne wiernych (christifideles), szczególnie wiernych świeckich. Z drugiej zaś strony właśnie $\mathrm{w}$ centralnych księgach nowego kodeksu po raz pierwszy Słowo i Sakrament ukazują się jako elementy nośne całej struktury kościelnej ${ }^{57}$.

Na koniec, w porównaniu z Kodeksem z 1917 r., Kodeksy promulgowane przez Jana Pawła II ukazują dwie nowości fundamentalne dla hermeneutyki kanonistycznej, a przez to ważne dla umotywowania, przynajmniej w części i post factum, powstania tych Kodeksów, pomimo oporu ze strony tych, którzy podczas prac komisji opowiadali się za koniecznością dekodyfikacji prawa w Kościele katolickim. Pierwsza nowość ukazuje się w fakcie, że nowa kodyfikacja ustaw kanonicznych nie jest na pierwszym miejscu motywowana koniecznością sformułowania i rozumowej systematyzacji norm, ale koniecznością rozwinięcia ich według związków z prawdami wiary i Tradycji kościelnej ${ }^{58}$. Dlatego też w ostatecznej analizie zasada pewności teologicznej przeważa nad zasadą pewności prawnej. Druga nowość ujawnia się w zmianie podstawowego podmiotu całej struktury jurydyczno-kościelnej: nie jest to już duchowny, ale christifidelis, to jest wierny! Oznacza to, że ochrzczony, jako taki, jest postacia pierwotna, będącą bazą dla postaci świeckiego, duchownego i zakonnika, a poprzez to jest pierwszym podmiotem praw i obowiązków w Kościele, tajemnicy komunii.

57 Dla szczegółowego zapoznania się z systematyką nowego kodeksu, zob. H. Schmitz, De ordinatione systematica novi Codicis Iuris Canonici recogniti, „Periodica” 68(1979), s. $171-200$.

${ }^{58} \mathrm{Na}$ temat aspektów materialnych i problemów jakie pojawiły się w związku z przystąpieniem do nowej kodyfikacji prawa Kościoła, zob. E. Corecco, Presupposti culturali ed ecclesiologici del nuovo Codex, [w:] S. Ferrari (red.), Il nuovo Codice di Diritto Canonico. Aspetti fondamentali della codificazione postconciliare, Bologna 1983, s. 37-68; o nieodzowności zdawania sobie sprawy z powiązań pomiędzy wiarą i normą prawną w tych pracach kodyfikacyjnych mówił papież Benedykt XVI: "Związek ze wspomnianym wyżej tematem - poprawnej interpretacji wiary - z pewnością nie sprowadza się do czysto semantycznego podobieństwa, biorąc pod uwagę, że prawo kanoniczne znajduje w prawdach wiary swoją podstawę i sens oraz że lex agendi powinna odzwierciedlać lex credendi", Benedetto XVI, Discorso in occasione dell'inaugurazione dell'anno giudiziario del Tribunale della Rota Romana. 21.01.2012, AAS 104(2012) 103-107. 
Wszystkie te nowości mają decydujące znaczenie również na poziomie interpretacji i aplikacji całego obowiązującego prawa kanonicznego. To właśnie na poziomie interpretacji i aplikacji ustaw kanonicznych ujawnia się najbardziej geniusz Jana Pawła II.

\subsection{Współrzędne ustalone przez Jana Pawła II dla rozwoju hermeneutyki kanonistycznej w służbie misji}

Jak podczas rewizji Kodeksu kładziono akcent na poszukiwanie głębokich racji norm kanonicznych (teologicznych i fundamentalnych), tak zaraz po promulgacji KPK z 1983 r. zainteresowanie kanonistów przesunęło się na kwestię interpretacji i aplikacji prawa kościelnego ${ }^{59}$. Jan Paweł II uprzedza to nie tylko chronologicznie poprzez natychmiastowe utworzenie Papieskiej Rady ds. Interpretacji Tekstów Prawnych. Ta inicjatywa, jak przystało na wielkiego specjalistę od komunikacji, jasno ukazuje dwie rzeczy. Przede wszystkim, że papież był świadom, iż było czymś niezwykle ważnym, aby Kościół posiadał solidną i uzasadnioną technikę interpretacyjna, ponieważ każdy przekaz, również prawny, „,nabiera właściwej formy w momencie komunikowania go zainteresowanym" ${ }^{\prime 60}$. Po drugie ukazuje w sposób zdecydowany wolę posiadania dykasterii, będącej w stanie „promować dyscyplinę wspólną dla całego Kościoła”, analogicznie do funkcji spełnianej przez Kongregację Nauki Wiary w porządku obowiązku i woli „promowania i obrony jedności wiary”"61.

To jasne zakorzenienie eklezjologiczne, jakie Jan Paweł II daje nowej dykasterii, z jednej strony podkreśla fakt, że jej zadanie nie ogranicza się jedynie do elementu czysto technicznej interpretacji, ale rozciąga się również na etap formacji całego złożonego systemu kanonicznego ${ }^{62}$. $\mathrm{Z}$ drugiej

59 Zob. J. Herranz Casado, L'interpretazione autentica: il Pontificio Consiglio per l'interpretazione dei testi legislativi, [w:] Il diritto della Chiesa. Interpretazione e prassi, Città del Vaticano 1996, s. 65.

${ }^{60}$ V. Frosini, Lezioni di teoria dell'interpretazione giuridica, Roma 1989, s. 108.

${ }^{61}$ To rozjaśniające porównanie zostało zaproponowane przez byłego Przewodniczącego Papieskiej Rady ds. Interpretacji Tekstów Prawnych, na podstawie nauczania KK 23, zob. J. Herranz Casado, L'interpretazione autentica, s. 66.

62 Od Annuario Pontificio 2000 nazwa nowej dykasterii („Papieska Rada ds. Tekstów Prawnych") nie odnosi się już do interpretacji, ale zasada jej działania i jej kompetencje pozostają niezmienione; więcej w tym temacie, zob. G. Incitti, L'interpretazione e il Pontificio Consiglio per (l'interpretazione dei) $i$ testi legislativi, [w:] Associazione Canonistica Italiana, Fondazione del diritto. Tipologia e interpretazione della nuova canonistica, Milano 2001, s. 155. 
zaś strony, jako iż pierwszorzędnym zadaniem tego nowego organizmu jest $\mathrm{tzw}$. autentyczna interpretacja $\mathrm{w}$ formie ustawy (per modum legis) ${ }^{63}$, to jest osobliwa forma interpretacji, która nie ma stosownego odpowiednika w prawodawstwie cywilnym ${ }^{64}$, poprzez jego ustanowienie Jan Paweł II pokazuje, że jest w pełni świadomy specyfiki prawa kościelnego i konieczności wspomagania efektywnej poprawy zarówno w technice legislacyjnej, jak też w aktualizacji komunii również na poziomie zarządzania Kościołem. Dokonuje się to poprzez interpretację ustaw kościelnych. Tym samym Jan Paweł II wyciska na hermeneutyce kanonistycznej III Tysiąclecia potrójne ukierunkowanie: ożywia kanonistyczną tradycję interpretacji ustaw kościelnych, poprzez odczytywanie znaków czasu; nadaje hermeneutyce kanonistycznej w jej całości nowe i pewne podstawy; otwiera drogę dla późniejszych modyfikacji instytucji prawnych Kościoła katolickiego w duchu misyjnym.

Paralelizm pomiędzy funkcją Papieskiej Rady ds. Interpretacji Tekstów Prawnych i Kongregacji Nauki Wiary ma swoje głębokie uzasadnienie, którego należy poszukiwać w ciągłej interreakcji pomiędzy teologią dogmatyczną i prawem kanonicznym ${ }^{65}$. Rzeczywiście, jak już zostało to ukazane w odległym 1980 r. przez Eugenio Corecco we Fryburgu ${ }^{66}$, czterem głównym etapom rozwoju teologii dogmatycznej odpowiadają cztery etapy rozwoju prawa kanonicznego. Wskazówka metodologiczna udzielona przez Sobór Watykański II pozwala na ustanowienie interesującego paralelizmu pomiędzy odnową epistemologiczną obserwowaną w kanonistyce posoborowej, a charakterem prawa kanonicznego pierwszego tysiąclecia, w przeważającej mierze mądrościowym, niczego nie ujmując nowym fundamentom eklezjologicznym, ukazanym przez nauczanie soborowe na temat Kościoła jako komunii, ani przywróconemu zainteresowaniu centralnym miejscem antropologii, jakie przejawia nauka prawa ka-

${ }^{63} \mathrm{Na}$ temat różnych form interpretacji, zob. L. Müller, Authentische Interpretation Auslegung kirchlicher Gesetze oder Rechtsfortbildung?, "Archiv für Katholisches Kirchenrecht" 1995 , t. 164 , s. 353-375.

${ }^{64} \mathrm{Na}$ ten temat zob. J. Herranz Casado, L'interpretazione autentica, s. 68; R.J. Castillo Lara, De iuris canonici authentica interpretatione in actuositate Pontificiae Commissionis adimplendae, "Communicationes" 20 (1988), s. 267.

${ }^{65}$ Zob. F. Suárez, De legibus, Lib. VI: De interpretatione, mutatione et cessatione legis, [w:] Opera Omnia, t. 5-6, Paris 1856, cyt. za: J. Herranz Casado, L'interpretazione autentica, s. 67.

${ }_{66}$ Zob. E. Corecco, Considerazioni sul problema dei diritti fondamentali del cristiano nella Chiesa e nella Società. Aspetti metodologici della questione, [w:] G. Borgonovo, A. Cattaneo (red.), Eugenio Corecco. Ius et communio. Scritti di Diritto Canonico, t. 1, Lugano-Casale Monferrato 1997, s. 246-253. 
nonicznego. Nie jest oczywiście bez znaczenia wpływ, jaki wywarł Jan Paweł II poprzez swoje działanie na poziome zarządzania, legislacji i interpretacji podczas swojego długiego i bogatego pontyfikatu.

Wręcz przeciwnie, fakt, że Kościół katolicki, jako komunia Kościołów (communio Ecclesiarum) posiada dwa Kodeksy prawa kanonicznego, jest zupełną nowościa, która pokazuje, że pluralizm prawny jest niezaprzeczalnym faktem, uznanym przez najwyższą władzę kościelną. Założenia, które doprowadziły do tego epokowego momentu kodyfikacji przez Kościół katolicki własnego prawa, zasady ustalone w sposób niezwykle jasny przez konstytucję apostolska, którą został promulgowany pierwszy z dwóch kodeksów, są ewidentnie niezbędne dla poprawnej interpretacji obowiązujących ustaw kanonicznych.

Ale co jest istotą tych dążeń? Precyzuje to sam Jan Paweł II: przede wszystkim ten podwójny wysiłek kodyfikacyjny „może być pojmowany jako wielki pas transmisyjny przenoszący na język kanonistyczny [...] soborową eklezjologię"67; następnie, chcąc właściwie odpowiedzieć na kwestię dotyczącą samej natury obu Kodeksów prawa kanonicznego „trzeba przypomnieć owo długie dziedzictwo prawa, które zawiera się w księgach Starego i Nowego Testamentu i z którego cała tradycja prawna i prawodawcza Kościoła się wywodzi jakby ze swojego pierwszego źródła".

W świetle takich stwierdzeń wydaje się być wystarczająco jasne, że celem podwójnej kodyfikacji kanonistycznej „nie jest bynajmniej zastąpienie w życiu Kościoła lub wiernych wiary, łaski, charyzmatów a zwłaszcza miłości. Przeciwnie, w Kodeksie chodzi raczej o to, aby rodził taki porządek społeczności kościelnej, który - przyznając główne miejsce miłości, łasce i charyzmatom - jednocześnie ułatwiałby ich uporządkowany postęp w życiu czy to w społeczności kościelnej, czy to poszczególnych ludzi, którzy do niej należą. Kodeks będąc podstawowym dokumentem ustawodawczym Kościoła, opartym na dziedzictwie prawnym i ustawodawczym Objawienia i Tradycji, winien być uważany za niezbędne narzędzie, dzięki któremu jest zachowany należyty porządek tak w życiu indywidualnym i społecznym, jak i w działalności Kościoła"68.

Objawienie, Tradycja i Kodeks stanowią zatem konieczne fundamenty, które przyczyniają się do zdefiniowania specyficznej i złożonej struktury Kościoła.

${ }^{67}$ Jan Paweł II, Sacrae disciplinae leges, wers 18.

${ }^{68}$ Tamże, wers 16. 
Papież Jan Paweł II ukazał tę cechę dopełnienia nauki ${ }^{69}$ (Soboru) przez prawo kanoniczne skodyfikowane podczas oficjalnej prezentacji KPK 3 lutego 1983 r., używając obrazu trójkąta, który - w stosunku do aplikacji i interpretacji prawa kanonicznego, poprzez ścisły związek między życiem wiary i porządkiem prawnym Kościoła - ukazuje się jako nowa zasada metodologiczna i hermeneutyczna, której należy bezwarunkowo przestrzegać: „obok księgi zawierającej akta Soboru mamy teraz nowy Kodeks Prawa Kanonicznego, a to wydaje mi się być zestawieniem bardzo ważnym i znaczącym. [...] Kończąc, chciałbym nakreślić przed wami, jako wskazówkę i przypomnienie, jakby idealny trójkąt: na górnym wierzchołku jest Pismo Święte, na jednym z dolnych Akta Soboru Watykańskiego II, a na drugim nowy Kodeks Prawa Kanonicznego. Aby wznieść się w sposób uporządkowany i usystematyzowany od tych dwóch ksiąg, wypracowanych przez Kościół XX wieku, do tego najwyższego i niezmiennego wierzchołka, trzeba będzie przejść wzdłuż boków tego trójkąta, bez zaniedbań i niedopełnień, mając na uwadze konieczne powiązania: mam na myśli całe Magisterium poprzednich Soborów Ekumenicznych, jak również (pomijając oczywiście normy, które straciły swoją ważność lub zostały uchylone) to dziedzictwo mądrości jurydycznej, które należy do Kościoła"70.

Do tej "mądrości prawnej” należy z całą pewnością przekonanie, że w Bożym Miłosierdziu winno się poszukiwać najgłębszych korzeni (prima radix) całej historii zbawienia, a zatem również jego konkretnego urzeczywistnienia $\mathrm{w}$ sprawiedliwości i $\mathrm{w}$ równości wobec prawa (aequitas canonica $^{71}$. Podkreśla to jeszcze raz sam Jan Paweł II, kiedy w numerze 14 encykliki Dives in misericordia stwierdza: „Autentyczne miłosierdzie jest jakby głębszym źródłem sprawiedliwości. Jeśli ta ostatnia sama z siebie zdol-

${ }^{69}$ Tamże, wers 20; o dokumentach Soboru Watykańskiego II jako „kontekście” norm kodeksowych, zob. L. Müller, Die Lehre des zweiten Vatikanischem Konzils als Kontext zum Interpretation kirchenrechtiler Normen, „Archiv für Katholisches Kirchenrecht” 2000, t. 169, s. $469-481$.

${ }^{70}$ Giovanni Paolo II, Discorso di Giovanni Paolo II per la presentazione ufficiale del nuovo Codice di Diritto Canonico. 3.02.1983, http://w2.vatican.va/content/john-paul-ii/it/speeches/1983/ february/documents/hf_jp-ii_spe_19830203_nuovo-codice.html [dostęp: 9.08.2018 r.]; tekst także w: Ioannes Paulus II, A Summo Pontifice in aula supra porticum Vaticanae basilicae habita, ad novum Codicem Iuris Canonici, paucis ante diebus promulgatum, publice exhibendum, AAS 75(1983), pars I, 463; zob. również H. Schmitz, Wertungen des Codex Iuris Canonici. Versuch einer ersten Bilanz, "Archiv für Katholisches Kirchenrecht” 1985, t. 154, s. 19-57; L. Gerosa, La nuova ermeneutica canonistica di Giovanni Paolo II, [w:] L. Gerosa (red.), Giovanni Paolo II: Legislatore della Chiesa. Fondamenti, innovazioni e aperture, Città del Vaticano 2013, s. 33-48.

${ }^{71}$ Zob. W. Kasper, Misericordia. Concetto fondamentale del Vangelo, Brescia 2013, s. 151. 
na jest tylko rozsądzać pomiędzy ludźmi, rozdzielając wśród nich przedmiotowe dobra słuszną miara to natomiast miłość, i tylko miłość (także owa łaskawa miłość, którą nazywamy miłosierdziem) zdolna jest przywracać człowieka samemu człowiekowi”. Poza tym, jak stwierdza wnikliwy naukowiec zajmujący się fundamentami prawa kanonicznego, „właściwe zrozumienie rzeczywistości prawnej wymaga zdawania sobie zawsze sprawy z wzajemnego przeplatania się sprawiedliwych stosunków i konkretnego systemu [prawnego], w którym one istnieją i są wcielane w życie. Wizja prawa kanonicznego, która dla chęci podkreślenia swojej specyfiki ponadnaturalnej, odstawiłaby na boczny tor technikę kanonistyczną lub własny wymiar historyczny, zbytnio idealizowałaby swój przedmiot, a poprzez to nie odpowiadałoby całej prawdzie o tym, co jest sprawiedliwe w Kościele. Miałoby się wówczas w rękach wynaturzoną abstrakcję, która nijak odpowiadałaby temu, czym rzeczywiście jest Kościół Chrystusowy w swojej ziemskiej pielgrzymce"72. Rozeznanie zaś poprzez własną pracę hermeneutyczną życiowego i obiektywnego związku pomiędzy normą kanoniczną i całą prawdą chrześcijańskiego doświadczenia prowadzi zawsze zarówno do odkrycia głębokiej, mistycznej motywacji, która prowadziła, ukierunkowała pracę prawodawcy kościelnego, jak też do unaocznienia jej najważniejszych dla misyjnej pracy Kościoła aspektów.

Co się tyczy odkrycia tych głębokich, mistycznych motywacji, które ukierunkowały aktywność Jana Pawła II jako prawodawcy, wystarczy tutaj wspomnieć, że jego zgłębianie nauczania św. Jana od Krzyża pozwoliło mu na wyeksponowanie jednocześnie dwóch filarów eklezjologii i antropologii nauczanej przez Sobór Watykański II: z jednej strony mistyczne małżeństwo nie jest tylko cenionym terminem duchowości karmelitańskiej, ale koncepcja która rzuca światło na tajemnicę Kościoła, jako misterium komunii, to jest rzeczywistości, w której communio jest podstawową kategoria, o naturze strukturalnej i antropologicznej ${ }^{73}$; $\mathrm{z}$ drugiej strony koncepcja osoby ludzkiej nie jest tylko pochodną teologii trynitarnej, ale kategorią która podkre-

${ }^{72}$ C.J. Errázuriz M., Il diritto e la giustizia nella Chiesa. Per una teoria fondamentale del diritto canonico, Milano 2000, s. 212.

${ }^{73}$ Ten sam synod biskupów z 1985 r. stwierdza wprost: „Kościół jest w Chrystusie niejako sakramentem, czyli znakiem i narzędziem wewnętrznego zjednoczenia z Bogiem i jedności całego rodzaju ludzkiego" (KK 1). W wizji tej zawarta jest pośrednio idea Kościoła, jako communio cum Deo ed hominibus, która będzie podstawową i centralną ideą dokumentów soborowych i uczyni z eklezjologii komunii „fundament dla porządku Kościoła, a przede wszytskim dla poprawnej relacji pomiędzy jednością i mnogością w Kościele" (Synodus Episcoporum, Relatio finalis. Ecclesia sub verbo Dei mysteria Christi celebrans pro 
śla naturę wspólnotową każdego człowieka, ponieważ „Syn Boży, przez wcielenie swoje zjednoczył się jakoś z każdym człowiekiem"74.

Odnośnie oddziaływania tej koncepcji legis canonicae na aktywność misyjną Kościoła, wystarczy tutaj wspomnieć na słowa wypowiedziane przez papieża Franciszka: jeśli w kanonistyce średniowiecznej odnajduje się motywację do określenia natury ustaw kościelnych jako iustitia dulcore misericordiae temperata ${ }^{75}$, z pewnością jest zasługą Jana Pawła II dostrzeżenie jak misja Kościoła w III Tysiącleciu może być pobudzona tylko wówczas, gdy reforma struktur kanonicznych w duchu misyjnym będzie w stanie klarownie ukazać moc odtwórczą Bożego Miłosierdzia. Powiedział to sam papież Franciszek: „On - święty Jan Paweł II - przeczuł, że był to czas miłosierdzia"76.

\section{Podsumowanie i postulat}

Wkład wniesiony przez Jana Pawła II do rozwoju prawa kanonicznego, kanonistyki i jej hermeneutyki jest zatem wielki i niezaprzeczalny. Dopiero teraz rozpoczęto jednak pracę nad wydobyciem najgłębszego i innowacyjnego sensu tego wkładu, aby móc potem rozwinąć wszystkie jego konsekwencje praktyczne dla porządku misji i nowej ewangelizacji.

Nie można zapomnieć, że to sam Jan Paweł II, pod koniec swojego pontyfikatu zwierza się, mówiąc: „Wszyscy próbują mnie zrozumieć od zewnątrz. Ja zaś mogę być zrozumiany tylko od wewnątrz"77. A zgłębianie zależności pomiędzy jego doświadczeniem mistycznym (bez mistyki, jak mówi papież Franciszek, chrześcijanie nie mogą dokonać wielkich rzeczy $^{78}$ ) a jego aktywnością jako prawodawcy Kościoła Powszechnego

salute mundi, Città del Vaticano 1985, II c, La Chiesa come comunione, 1); zob. Jan Paweł II, Posynodalna Adhortacja Apostolska "Christifideles laici", 19.

${ }^{74}$ Jan Paweł II, Redemptor hominis, 13, gdzie cytuje dosłownie teks soborowy KK, 22.

${ }^{75} \mathrm{Na}$ temat pochodzenia tego określenia (giustizia mitigata dalla dolcezza della misericordia), zob. przypis 37.

${ }^{76}$ Francesco, Camminare con Gesù. Il cuore della vita cristiana, G. Vigini (red.), Cinisello Balsamo 2014, s. 138.

77 S. Oder, S. Gaeta, Perchè è Santo. Il vero Giovanni Paolo II raccontato dal postulatore della causa di beatificazione, Milano 2010, s. 139.

${ }^{78}$ Franciszek, Encyklika "Laudato Si”" Ojca Świętego Franciszka poświęcona trosce o wspólny dom. 24.05.2015, 216, http://w2.vatican.va/content/francesco/pl/encyclicals/documents/papa-francesco_20150524_enciclica-laudato-si.html [dostęp: 08.08.2018 r.]. Pierwsze 
w służbie misji kościelnej w III Tysiącleciu naprawdę dopiero się rozpoczęło i oczekują na nowe i pogłębione analizy.

Jak pisze Karol Wojtyła w swoim poemacie Pieśn o Bogu ukrytym, poezji mówiącej o Eucharystii, a więc o wszystkim dla życia chrześcijańskiego i braterskiej komunii (zob. KK 11, 1; SC 10, 1):

„Z wolna słowom odbieram blask [...]

$\mathrm{z}$ wolna wszystko napełniam nicością,

która czeka na dzień stworzenia.

To dlatego, by otworzyć przestrzeń

Dla twych wyciągniętych rąk.”

tłum. ks. K. Nowicki

Słowa kluczowe: Jan Paweł II, Kodeks Prawa Kanonicznego, interpretacja prawa kanonicznego

\section{Bibliografia}

Ahlers R., Communio Eucharistica. Eine kirchenrechtliche Untersuchung zur Eucharistielehre in Codex Iuris Canonici, Regensburg 1990.

Arrieta J., Barmherzigkeit und kanonisches Recht. Die Erfahrung des lateinischen Kirchenrechts und die hermeneutische Aufgabe der Mediation, "Archiv für Katholisches Kirchenrecht" 2015, t. 184, s. 16-33.

Benedetto XVI, Discorso in occasione dell'inaugurazione dell'anno giudiziario del Tribunale della Rota Romana. 21.01.2012, AAS 104(2012) 103-107.

Calvi M., I santuari nel nuovo Codice di diritto canonico, "Quaderni di Diritto Ecclesiale" 1989, nr 2, s. 181-187.

Castillo Lara R.J., De iuris canonici authentica interpretatione in actuositate Pontificiae Commissionis adimplendae, „Communicationes” 20 (1988), s. 265-287.

Cazzago A., Cristianesimo d'Oriente e d'Occidente in Giovanni Paolo II, Milano 1996.

Corecco E., Considerazioni sul problema dei diritti fondamentali del cristiano nella Chiesa e nella Società. Aspetti metodologici della questione, [w:] G. Borgonovo, A. Cattaneo (red.), Eugenio Corecco. Ius et communio. Scritti di Diritto Canonico, t. 1, Lugano-Casale Monferrato 1997, s. 245-278.

próby analizy fundamentów i charakterystyki doświadczenia mistycznego Jana Pawła II, jak również jego konsekwencji na płaszczyźnie działalnosci legislacyjnej, zob. L. Gerosa, Gdzie rodzi się prawdziwy czlowiek?, s. 24-39, 42-56. 
Corecco E., Il valore della norma canonica in rapporto alla salvezza, [w:] G. Borgonovo, A. Cattaneo (red.), Eugenio Corecco. Ius et communio. Scritti di Diritto Canonico, t. 1, Lugano-Casale Monferrato 1997, s. 57-64.

Corecco E., Presupposti culturali ed ecclesiologici del nuovo Codex, [w:] S. Ferrari (red.), Il nuovo Codice di Diritto Canonico. Aspetti fondamentali della codificazione postconciliare, Bologna 1983, s. 37-68.

Corecco E., Prospettive per la "Lex Ecclesiae fundamentalis" e la revisione del diritto canonico nel documento di Puebla, „Il Diritto Ecclesiastico” 1980, t. 91, z. 1, s. 3-23.

Dalla Torre G., Giustizia e misericordia, „Ephemerides Iuris Canonici” 2016, t. 56, z. 1, s. 175-194.

Dalla Torre G., Il codice di diritto canonico, [w:] G. La Bella (red.), Pio X e il suo tempo, Bologna 2003, s. 311-332.

Dalla Torre G., Santità e diritto. Sondaggi nella storia del diritto canonico, Torino 1999.

De Meester C., L'offerta all'amore misericordioso, [w:] Teresa di Lisieux. Vita, dottrina, ambiente, Cinisello Balsamo 1996.

Erdö P., Rigidità ed elasticità delle strutture normative nel dialogo ecumenico, [w:] La legge canonica nella vita della Chiesa. Indagine e prospettive nel segno del recente magistero pontificio. Atti del Convegno di studio tenutosi nel XXV anniversario della promulgazione del Codice di Diritto Canonico, Città del Vaticano 2008, s. 149-178.

Errázuriz M. C.J., Il diritto e la giustizia nella Chiesa. Per una teoria fondamentale del diritto canonico, Milano 2000.

Fagiolo V., Problemi giuridici riguardanti i santuari, „La Madonna” 35(1987), s. $58-75$.

Fantappié C., Ecclesiologia e canonistica, Venezia 2015.

Fantappié C., "Modernità" e "antimodernità" di Pio X, [w:] G. Brugnotto, G. Romanato (red.), Riforma del Cattolicesimo. Le attività e le scelte di Pio X, Città del Vaticano 2016, s. 3-37.

Feliciani G., La disciplina canonica dei santuari, [w:] G. Dammacco, G. Otranto (red.), Profili giuridici e storia dei santuari cristiani in Italia, Bari 2004, s. 31-44.

Fisichella R., Prefazione, [w:] R. Fisichella (red.), Giovanni Paolo II. Tutte le encicliche, Città del Vaticano 2010, s. 759-769.

Francesco, Camminare con Gesù. Il cuore della vita cristiana, G. Vigini (red.), Cinisello Balsamo 2014.

Francesco, Esortazione apostolica "Evangelii gaudium”, Città del Vaticano 2013.

Francesco, Lettera del Santo Padre Francesco al Gran Cancelliere della Pontificia Universidad Católica Argentina, http://w2.vatican.va/content/francesco/it/ letters/2015/documents/papa-francesco_20150303_lettera-universita-cattolica-argentina.html [dostęp: 08.08.2018 r.].

Franciszek, Encyklika "Laudato Si”" Ojca Świętego Franciszka poświęcona trosce o wspólny dom. 24.05.2015, http://w2.vatican.va/content/francesco/pl/en- 
cyclicals/documents/papa-francesco_20150524_enciclica-laudato-si.html [dostęp: 08.08.2018 r.].

Franciszek, List apostolski motu proprio "Mitis Iudex Dominus Iesus" reformujacy kanony Kodeksu Prawa Kanonicznego dotyczace spraw o orzeczenie nieważności małżństwa. 8.09.2015 r., http://w2.vatican.va/content/francesco/pl/motu_ proprio/documents/papa-francesco-motu-proprio_20150815_mitis-iudex-dominus-iesus.html [dostęp: 9.08.2018 r.].

Frosini V., Lezioni di teoria dell'interpretazione giuridica, Roma 1989.

Gerosa L., Dove nasce l'uomo vero? Per un esercizio autentico della Misericordia, Lugano-Siena 2016.

Gerosa L., Gdzie rodzi sie prawdziwy człowiek? Doświadczenie autentycznego Miłosierdzia, Białystok 2016.

Gerosa L., Interpretacja prawa w Kościele. Zasady, wzorce, perspektywy, Kraków 2003.

Gerosa L., La nuova ermeneutica canonistica di Giovanni Paolo II, [w:] L. Gerosa (red.), Giovanni Paolo II: Legislatore della Chiesa. Fondamenti, innovazioni e aperture, Città del Vaticano 2013, s. 33-48.

Gerosa L., L'interpretazione della legge nella Chiesa. Principi, paradigmi, prospettive, Lugano 2001.

Giovanni Paolo II, Al mondo della cultura nell'Aula Magna dell'Università Cattolica di Lublino. La società attende dalle sue Università il consolidamento delle proprie soggettività. 9.06.1987, [w]: Insegnamenti di Giovanni Paolo II, Città del Vaticano 1987, t. 10, cz. 2, s. 2054-2063.

Giovanni Paolo II, Catechesi sul segno sacramentale del matrimonio. 30.05.1984, [w:] Insegnamenti di Giovanni Paolo II, t. 7, cz. 1, Città del Vaticano 1984, s. $1560-1568$.

Giovanni Paolo II, Discorso di Giovanni Paolo II al Tribunale della Rota Romana in occasione dell'inaugurazione dell'Anno Giudiziario. 29.01.2005, http://w2.vatican.va/content/john-paul-ii/it/speeches/2005/january/documents/hf_jpii_spe_20050129_roman-rota.html [dostęp: 9.08.2018 r.].

Giovanni Paolo II, Discorso di Giovanni Paolo II al Tribunale della Rota Romana in occasione dell'inaugurazione dell'Anno Giudiziario, AAS 97(2005) 164-166.

Giovanni Paolo II, Il discorso a Częstochowa dopo "l'appello di Jasna Góra". Non è lecito permettere la degradazione degli uomini mentre ci si è assunti per essi la responsabilità davanti alla storia. 12.06.1987, [w:] Insegnamenti di Giovanni Paolo II, Città del Vaticano 1987, t. 10, cz. 2, s. 2180-2185.

Giovanni Paolo II, Discorso di Giovanni Paolo II per la presentazione ufficiale del nuovo Codice di Diritto Canonico. 3.02.1983, http://w2.vatican.va/content/john-paul-ii/it/speeches/1983/february/documents/hf_jp-ii_spe_19830203_ nuovo-codice.html [dostęp: 9.08.2018 r.].

Giovanni Paolo II, L'omelia della Messa a Fatima. Il messaggio di Fatima si comprende alla luce dell'amore materno di Maria. 13.05.1982, [w :] Insegnamenti di Giovanni Paolo II, Città del Vaticano 1982, t. 5, cz. 2, s. 1567-1585. 
Giovanni Paolo II, L'omelia durante Celebrazione della Parola nell'Università Cattolica di Lublino. Università! Alma mater! Se servi la verità, servi la libertà, la liberazione dell'uomo e della nazione. Servi la vita! 9.06.1987, [w:] Insegnamenti di Giovanni Paolo II, Città del Vaticano 1987, t. 10, cz. 2, s. 2064-2072.

Giovanni Paolo II, Omelia alla messa celebrata a Lugano. La Chiesa nella dimensione universale e locale è l'ambiente della nuova esistenza dell'uomo. 12.06.1984, [w:] Insegnamenti di Giovanni Paolo II, Città del Vaticano 1984, t. 7, cz. 1, s. 1676-1683.

Grossi P., Valore e limiti della codificazione del diritto (con qualche annotazione sulla scelta codicistica del legislatore canonico), [w:] A. Cattaneo (red.), L'eredità giuridica di San Pio X, Venezia 2006, s. 141-154.

Hauke M. (red.), Die Marienerscheinungen - 100 Jahre danach: Geschichte, Rezeption und Bedentung, Regensburg 2017.

Herranz Casado J., L'interpretazione autentica: il Pontificio Consiglio per l'interpretazione dei testi legislativi, [w:] Il diritto della Chiesa. Interpretazione e prassi, Città del Vaticano 1996, s. 65-93.

Herranz J., F.J. Errázuriz, J.I. Arrieta, La salus animarum nell'esperienza giuridica della Chiesa, „Ius Ecclesiae” 12 (2000), s. 291-529.

Herranz J., Il Codice di Diritto canonico e il successivo sviluppo normativo, [w:] La legge canonica nella vita della Chiesa. Indagine e prospettive nel segno del recente magistero pontificio. Atti del Convegno di studio tenutosi nel XXV anniversario della promulgazione del Codice di Diritto Canonico, Città del Vaticano 2008, s. 47-59.

Incitti G., L'interpretazione e il Pontificio Consiglio per (l'interpretazione dei) $i$ testi legislativi, [w:] Associazione Canonistica Italiana, Fondazione del diritto. Tipologia e interpretazione della nuova canonistica, Milano 2001, s. 153-178.

Ioannes Paulus II, A Summo Pontifice in aula supra porticum Vaticanae basilicae habita, ad novum Codicem Iuris Canonici, paucis ante diebus promulgatum, publice exhibendum, AAS 75(1983), pars I, 455-463.

Ioannes Paulus II, Litterae Enciclicae de Beata Maria Virgine in vita Ecclesiae peregrinantis "Redemptoris Mater", AAS 79(1987) 361-433.

Jan Paweł II, Encyklika "Dives in Misericordia", [w:] Fisichella R. (red.), Giovanni Paolo II. Tutte le encicliche, Città del Vaticano 2010.

Jan Paweł II, Encyklika "Redemptor Hominis", [w:] Encykliki Ojca Świętego Jana Pawła II, t. 1, Kraków 1996, s. 1-53.

Jan Paweł II, Konstytucja Apostolska „Pastor bonus”, AAS 80(1988) 841-934.

Jan Paweł II, Konstytucja Apostolska "Sacrae disciplinae leges”, AAS 75(1983), pars II.

Jan Paweł II, List Apostolski "Novo millennio ineunte”. 6.01.2001, AAS 93(2001) 266-309.

Jan Paweł II, Posynodalna Adhortacja Apostolska "Christifideles laici". 30.12.1988, AAS 81(1989) 393-521.

Jan Paweł II, Przemówienie do "Common Law Society of Great Britain and Ireland". 22.05.1992, „Communicationes” 24 (1992). 
Kasper W., Misericordia. Concetto fondamentale del Vangelo, Brescia 2013.

Lethel F.M., La luce di Cristo nel cuore della Chiesa. Giovanni Paolo II e la teologia dei santi. Esercizi spirituali con Benedetto XVI, Città del Vaticano 2011.

Meisner J., Als Maria das Heft in die Hand nahm, "Die Tagespost" 13.09.2016.

Minelli C., Pio X e la sistematica del Codex Iuris Canonici, [w:] G. Brugnotto, G. Romanato (red.), Riforma del Cattolicesimo. Le attività e le scelte di Pio X, Città del Vaticano 2016, s. 293-324.

Müller H., Aequitas canonica, [w:] W. Kasper (red.), Lexikon für Theologie und Kirche, t. 1, Friburg-Basel-Rom-Wien 1993, kol. 185.

Müller H., Utrum "communio" sit principium formale-canonica novae codificationis Iuris Canonici Ecclesiae Latinae?, „Periodica” 1985, t. 74, s. 85-108.

Müller L., Authentische Interpretation - Auslegung kirchlicher Gesetze oder Rechtsfortbildung?, „Archiv für Katholisches Kirchenrecht” 1995, t. 164, s. 353375.

Müller L., Die Lehre des zweiten Vatikanischem Konzils als Kontext zum Interpretation kirchenrechtiler Normen, „Archiv für Katholisches Kirchenrecht” 2000, t. 169 , s. $469-481$.

Müller L., Fede e diritto. Questioni fondamentali del diritto canonico, Lugano 2006.

Oder S., S. Gaeta, Perchè è Santo. Il vero Giovanni Paolo II raccontato dal postulatore della causa di beatificazione, Milano 2010.

Ratzinger J., Un'interpretazione dei segni dei tempi per il cammino della Chiesa e dell'umanità. Conferenza di presentazione dell'enciclica "Redemptoris Mater", „L'Osservatore Romano" 26.03.1987.

Ravasi G., Cantico dei Cantici... come sigillo sul cuore, Cinisello Balsamo 2011.

Riccardi A., Giovanni Paolo II. La biografia, San Paolo-Cinisello Balsamo 2011.

Romanato G., Pio X. La vita di papa Sarto, Milano 1992.

Schmitz H., De ordinatione systematica novi Codicis Iuris Canonici recogniti, „Periodica" 68 (1979), s. 171-200.

Schmitz H., Wertungen des Codex Iuris Canonici. Versuch einer ersten Bilanz, „Archiv für Katholisches Kirchenrecht" 1985, t. 154, s. 19-57.

Siccardi C., San Pio X. Vita del Papa che ha ordinato e riformato la Chiesa, Cinisello Balsamo 2014.

Sobański R., La Chiesa e il suo diritto. Realtà teologica e giuridica del diritto ecclesiale, Torino 1993.

Stein E., La scelta di Dio. Lettere, Roma 1974.

Suárez F., De legibus, Lib. VI: De interpretatione, mutatione et cessatione legis, [w:] Opera Omnia, t. 5-6, Paris 1856.

Synodus Episcoporum, Relatio finalis. Ecclesia sub verbo Dei mysteria Christi celebrans pro salute mundi, Città del Vaticano 1985.

Thibaut A.F.J., F.C. Savigny, La polemica sulla codificazione, G. Marini (red.), Napoli 1982.

Vircondelet A., Giovanni Paolo II. La biografia del Papa che ha cambiato la storia, Turyn 2005. 
Wojtyła K. - Jan Paweł II, Ewangelia a sztuka. Rekolekcje dla artystów, Kraków 2016.

Wojtyła K., Il Vangelo e l'arte. Esercizi spirituali per gli artisti, Città del Vaticano 2013.

Zani L., Był człowiekiem, byt świętym, Kraków 2014.

Zani L., Era santo, era uomo. Il volto privato di Papa Wojtyla, Milano 2011.

\section{INTERPRETATION OF CANONIC LAWS AND NEW EVANGELIZATION: THE INNOVATIVE LESSON OF SAINT JOHN PAUL II}

\section{S u m m a r y}

By implementing the fundamental goal of the article, which is to highlight the impact of John Paul II on the development of canonic studies, the author starts by pointing out the theological focus fundamental for the contemporary canonist, outlined with reference to coinciding anniversaries (John Paul II's visit at the Catholic University of Lublin, the promulgation of 1917 Code of Canon Law, Fatima Apparitions and St Therese of Lisieux's offering herself to Merciful Love).

The extraordinary meaning of the Polish Pope for the renewal of Canon Law is shown by pointing out his legislative activeness and his contribution to the methodological and epistemological development of canonic studies. The author expresses his conviction that the picture thus created should be completed with conclusions drawn from the analysis of the connection between the mystic experience of John Paul II with his legislative activity.

Key words: John Paul II, Code of Canon Law, canon law interpretation

\section{ИНТЕРПРЕТАЦИЯ КАНОНИЧЕСКИХ ЗАКОНОВ И НОВАЯ ЕВАНГЕЛИЗАЦИЯ: ИННОВАЦИОННОЕ ЗАНАТИЕ СВЯТОГО ИОАННА ПАВЛА II}

$$
\text { Р ез о м е }
$$

Реализируя основную цель статьи, которой является особым вкладом Иоанна Павла II в развитии канонической науки, автор обращеет внимание на основное для современного канониста богословское направление, ссылаясь к совпадающим годовщинам (визиты Иоанна Павла II в Аюблинском Католическом Университете, обнародование Кодекса Канонического Права с 1917 г., Фатимское явление, а также пожертвования Милосердной Дюбви святой Тересой с Аизьё). Исключительное значение Папы-Поляка для обновления канонического права указано путем обращения внимания на его законодательную активность, а также вклад в методологическое и эпистемологичное развитие каноничной науки. 
Автор высловливает при этом убеждение, что созданная, таким образом, картина должна быть дополнена выводами, выведенных из анадиза связи мистического опыта Иоанна Павла II с его законодательной активностью.

Ключевые слова: Иоанн Павел II, Кодекс Канонического Права, интерпретация канонического права 